\title{
Lobulated Growth Pattern
}

National Cancer Institute

\section{Source}

National Cancer Institute. Lobulated Growth Pattern. NCI Thesaurus. Code C35891.

A morphologic finding indicating the presence of a cellular infiltrate forming lobules in a tissue sample. 